\title{
Estimating the growth effects of services sector: a cointegration analysis for Pakistan
}

\author{
Abdul Jalii ${ }^{1 *}$, Samia Manan ${ }^{1}$ and Sundus Saleemi ${ }^{2}$
}

${ }^{*}$ Correspondence:

jalil.hanif@gmail.com

1 School of Economics,

Quaid-i-Azam University,

Islamabad, Pakistan

Full list of author information

is available at the end of the article

\begin{abstract}
This article empirically tests the hypothesis of Pugno (Struct Change Econ Dyn 17:99$115,2006)$ that both business- and household-related services contribute in the economic growth of the country in the case of Pakistan over the period of 1960-2014. To accomplish the task, the study uses Johansen-Juselius cointegration test and autoregressive distributed lag bounds test to test the long-run relationship between the services sector and the economic growth of Pakistan. The tests reveal that the services sector has a long-run relationship with the economic growth of Pakistan. Furthermore, the estimation of cointegrating vector shows that the services sector positively contributes in the economic growth of Pakistan.
\end{abstract}

Keywords: Services sector, Economic growth, Pakistan, ARDL

\section{Background}

The important works of Kuznets (1957), Chenery (1979), Kuznets (1966, 1971), Rostow (1971), Chenery and Syrquin (1975), Baumol et al. (1989) and Echevarria (1997) on economic growth argue that growth of gross domestic product (GDP) is connected with variations in the share of services and the sectoral composition of GDP. Therefore, services sector has caught the attention of economists all around the world due to its increasing share in GDP and employment over the last decades. A plethora of research has covered the issue of rise in services sector across the world economies from many angles and different vantage points.

Over the last two decades, the emergence of economics of transport and tourism, economics of infrastructure and economics of financial sector development well recognizes the role of services in explaining the economic growth of economies. Particularly, Munnell (1992), Gramlich (1994) and Pradhan and Bagchi (2013) point out that the deficit of infrastructure may hurt the economic growth of emerging economies. Similarly, Roubini and Sala-i-Martin (1992), Levine (1997), Levine and Zervos (1998), Levine et al. (2000) and Jalil et al. (2010) document that the financial sector is one of the important determinants of economic growth of developing and developed countries. Therefore, we may say that the role of services sector in affecting the level and growth of

\section{Springer}

(c) 2016 Jalil et al. This article is distributed under the terms of the Creative Commons Attribution 4.0 International License (http:// creativecommons.org/licenses/by/4.0/), which permits unrestricted use, distribution, and reproduction in any medium, provided you give appropriate credit to the original author(s) and the source, provide a link to the Creative Commons license, and indicate if changes were made. 
output is implicitly recognized in the recent literature on economic growth. However, the role of services is not well researched in Pakistan.

Services sector has shown marked improvement in Pakistan as the share of services in GDP of Pakistan is 53.5 \% in 2011-2012 and growth rate of this sector was $4.5 \%$ in 2010-2011, and it accounts for one-third of total employment. Importantly, the services sector is further expected to emerge in the near future. Sundrum (1990) Illeris (1996) and Qin (2006) document that it is a natural process for a developing economy to evolve into a services-oriented economy. Furthermore, Pakistani government has a special eye on the services sector by promoting the policies on the development of infrastructure on Pakistan and financial sector development.

On the other hand, an important work of Baumol (1967) points out that increasing share of services sector in the GDP has a negative effect on the economic growth in the framework of unbalanced growth model. The unbalanced growth model postulates that the growth of services sector may decrease the overall improvement in the productivity of an economy, which ultimately leads to decrease in the economic growth of the economy (Qin 2006). The economy of Pakistan witnessed a miracle growth in GDP from 2000 to 2006. Indeed, the services sector was the major contributor in this miraculous economic growth. But suddenly that miracle evaporated and economy of Pakistan witnessed a free fall from $8 \%$ annual growth in 2006 to $2 \%$ growth in 2011 and 2012. It is argued that the economic growth of Pakistan was demand driven and that demanddriven growth ever remains shaky (Baumol 1967; Baumol et al. 1985).

With the increasing share of services sector in the presence of contradictory theoretical arguments, there is an imperative need to test the role of services sector in the case of Pakistani economy. The objective of this study is to test the Pugno (2006) hypothesis that services sector, irrespective of household or business, has a positive effect on the economic activities of an economy in the case of Pakistan over the period of 1960-2014. We argue that, despite the importance of services sector over the last two decades, there is no scientific study available in the literature on the economy of Pakistan. Therefore, this article will contribute in this way.

The findings of this paper suggest that the measure of services sector enters significantly positive in the growth regression of Pakistan. This implies that the services sector has a positive impact on the economic activities of Pakistan. To check the robustness of this finding, we take several business- and household-related service variables. All these variables confirm the previous results that the services-related variable enters significantly positive in the growth regression whether these are related to business or household activities like education- and health-related expenditure.

The study proceeds as follows: Section 2 sets the analytical framework; Sect. 3 covers the estimation strategies; variable construction and data sources are discussed in Sect. 4; Sect. 5 gives the empirical results; and Sect. 6 concludes the study.

\section{Analytical setting}

GDP is determined as the value added of agriculture, industrial and services sector. Therefore, consider the following production function-type relationship among GDP, agriculture, industry and services sector.

$$
\mathrm{GDP}_{t}=F\left(\mathrm{AGR}_{t}, \mathrm{IND}_{t}, \mathrm{SER}_{t}\right)
$$


where $\mathrm{AGR}_{t}$ is the output of agricultural sector, $\mathrm{IND}_{t}$ is industrial output and $\mathrm{SER}_{t}$ is the output of the services sector. Taking total differentiation for the linearization gives:

$$
\mathrm{dGDP}_{t}=F_{\mathrm{A}} \mathrm{dAGR}_{t}+F_{\mathrm{I}} \mathrm{dIND}_{t}+F_{\mathrm{S}} \mathrm{dSER}_{t}
$$

where $F_{\mathrm{A}}, F_{\mathrm{I}}$ and $F_{\mathrm{S}}$ are the partial derivatives of agricultural, industrial and services sector, respectively. Dividing Eq. 2 by GDP will give the economic growth:

$$
\frac{\mathrm{dGDP}}{\mathrm{GDP}}=\frac{F_{\mathrm{A}}}{\mathrm{GDP}} \mathrm{dAGR}_{t}+\frac{F_{\mathrm{I}}}{\mathrm{GDP}} \mathrm{dIND}_{t}+\frac{F_{\mathrm{S}}}{\mathrm{GDP}} \mathrm{dSER}_{t}
$$

Then, Eq. 3 can be augmented with sector output for getting the elasticities:

$$
\frac{\mathrm{dGDP}}{\mathrm{GDP}}=\frac{F_{\mathrm{A}}}{\mathrm{GDP}} \mathrm{dAGR}_{t} \frac{\mathrm{AGR}_{t}}{\mathrm{AGR}_{t}}+\frac{F_{\mathrm{I}}}{\mathrm{GDP}} \mathrm{dIND}_{t} \frac{\mathrm{IND}_{t}}{\mathrm{IND}_{t}}+\frac{F_{\mathrm{S}}}{\mathrm{GDP}} \mathrm{dSER}_{t} \frac{\mathrm{SER}_{t}}{\mathrm{SER}_{t}}
$$

By rearranging

$$
\frac{\mathrm{dGDP}}{\mathrm{GDP}}=\frac{\partial F}{\partial \mathrm{AGR}_{t}} \cdot \frac{\mathrm{AGR}_{t}}{\mathrm{GDP}_{t}} \cdot \frac{\mathrm{dAGR}_{t}}{\mathrm{AGR}_{t}}+\frac{\partial F}{\partial \mathrm{IND}_{t}} \cdot \frac{\mathrm{IND}_{t}}{\mathrm{GDP}_{t}} \cdot \frac{\mathrm{dIND}_{t}}{\mathrm{IND}_{t}}+\frac{\partial F}{\partial \mathrm{SER}_{t}} \cdot \frac{\mathrm{SER}_{t}}{\mathrm{GDP}_{t}} \cdot \frac{\mathrm{dSER}_{t}}{\mathrm{SER}_{t}}
$$

By simplification

$$
\frac{\mathrm{dGDP}}{\mathrm{GDP}}=\alpha_{\mathrm{A}} \cdot \frac{\mathrm{dAGR}_{t}}{\mathrm{AGR}_{t}}+\alpha_{\mathrm{I}} \cdot \frac{\mathrm{dIND}_{t}}{\mathrm{IND}_{t}}+\alpha_{\mathrm{S}} \cdot \frac{\mathrm{dSER}_{t}}{\mathrm{SER}_{t}}
$$

where $\alpha_{\mathrm{A}}, \alpha_{\mathrm{I}}$ and $\alpha_{\mathrm{S}}$ are sectoral output elasticities of agriculture, industry and services. So, the specification of Eq. 6 leads to model with variables $\frac{\mathrm{dGDP}_{\mathrm{GDP}}}{\mathrm{GDP}} \cdot \frac{\mathrm{dAGR}_{t}}{\mathrm{AGR}_{t}}, \cdot \frac{\mathrm{dIND}_{t}}{\mathrm{IND}}$ and $_{t} \frac{\mathrm{dSER}_{t}}{\mathrm{SER}_{t}}$.

Alternatively, Eq. 4 can be re arranged in share terms instead of elasticities. If we assume that there is perfect competition in the economy, then marginal product theory postulates that every sector will be compensated according to its marginal product. Therefore, $F_{\mathrm{A}}=w_{\mathrm{A}}, F_{\mathrm{I}}=w_{\mathrm{I}}$ and $F_{\mathrm{S}}=w_{\mathrm{S}}$ and Eq. 5 can be rewritten as:

$$
\frac{\mathrm{dGDP}}{\mathrm{GDP}}=w_{\mathrm{A} t} \cdot \frac{\mathrm{AGR}_{t}}{\mathrm{GDP}_{t}} \cdot \frac{\mathrm{dAGR}_{t}}{\mathrm{AGR}_{t}}+w_{\mathrm{I} t} \cdot \frac{\mathrm{IND}_{t}}{\mathrm{GDP}_{t}} \cdot \frac{\mathrm{dIND}_{t}}{\mathrm{IND}_{t}}+w_{\mathrm{S} t} \cdot \frac{\mathrm{SER}_{t}}{\mathrm{GDP}_{t}} \cdot \frac{\mathrm{dSER}_{t}}{\mathrm{SER}_{t}}
$$

And

$$
\frac{\mathrm{dGDP}}{\mathrm{GDP}}=W_{\mathrm{A} t} \cdot \frac{\mathrm{dAGR}_{t}}{\mathrm{AGR}_{t}}+W_{\mathrm{I} t} \cdot \frac{\mathrm{dIND}_{t}}{\mathrm{IND}_{t}}+W_{\mathrm{S} t} \cdot \frac{\mathrm{dSER}_{t}}{\mathrm{SER}_{t}}
$$

where $W_{\mathrm{A} t}, W_{\mathrm{I} t}$ and $W_{\mathrm{St}}$ are the shares of agriculture, industry and services sector in the total output. This implies that services sector has a pivotal role in explaining the GDP. Since the economy of Pakistan is in transition from developing economy and services sector has a lion's share in the GDP, the present study estimates the reduced-form bivariate model to examine the long-run effects of services sector on the aggregate real GDP. Following the estimable specification of Singh (2010):

$$
\ln g d p=\beta_{0}+\beta_{1} \ln s e r_{t}+u_{t}
$$

$\ln g d p$ is the natural log real GDP and lser is the natural log of services share. 
Since there is a theoretical controversy about the effect of services on the output of the economy, there is a need of testing the result of Eq. 9. For this purpose, we put a number of control variables for checking the robustness of the sign and significance of the services variable. The empirical investigation based on the production function suggests a number of variables effecting economic growth, for example physical capital stock (Lucas 1988), trade openness (Grossman and Helpman 1991; Lucas 1988; Young 1991) and inflation (Sidrauski 1967; Faria 2001). Therefore, the present article takes these factors in Eq. 9 as a control variable.

Furthermore, it is generally argued that the business services like wholesale and retail trade, finance and insurance, transport, storage and communication are effective in flourishing the economic growth and the household services are recognized as a burden for the growth of the economy. However, this puzzle is reconciled by Pugno (2006) in an endogenous growth model by considering that education, health care and cultural services, which form a large fraction of household services, contribute to human capital formation and hence to growth. Therefore, we shall include the share of different subsectors in the growth regression.

\section{Estimation strategy}

The time-series analysis suggests that the researchers should test the long-run relationship among the variables under consideration in case of non-stationary data series. The econometricians propose a number of cointegration techniques for test the longrun relationships among variables. The present study uses, Johansen $(1988,1991)$ and Johansen and Juselius (1990) bivariate cointegration tests to examine the long-run relationship between natural log of real GDP and natural log of share of services. Since this estimator is extensively discussed in the literature of theoretical and applied literature, we are not going to discuss here. Johansen $(1988,1991)$ and Johansen and Juselius (1990) are referred for further details.

However, this estimator can be applied in the case when the data series have the same order of integration. Therefore, testing the time properties of data series is a natural starting point in our case. A number of tests are discussed in the literature for this purpose. The present study uses augmented Dickey-Fuller (ADF) and Phillips-Perron tests to find out the order of integration of both the series. If the series have same order of integration, then we can use Johansen $(1988,1991)$ and Johansen and Juselius (1990) of cointegration.

If there exists cointegration relationship, then it implies that there is a long-run relationship between both variables. This further implies that there exists Granger causality between both variables in at least one direction. The error correction mechanism (ECM) was introduced by Sargan (1964) and then popularized by Engle and Granger (1987). This mechanism is used for correcting short-run disequilibrium in the long run and testing for long- and short-run causality among cointegrated data series. We specify the ECM for our bivariate model as follows:

$$
\Delta \ln g d p_{t}=a_{0}+\sum_{i=1}^{m} a_{1 i} \Delta \ln g d p_{t-i}+\sum_{i=1}^{n} a_{2 i} \Delta \ln \operatorname{ser}_{t-i}+\lambda E C M_{t-1}
$$




$$
\Delta \ln \operatorname{ser}_{t}=b_{0}+\sum_{i=1}^{m} b_{1 i} \Delta \ln \operatorname{ser}_{t-i}+\sum_{i=1}^{n} b_{2 i} \Delta \ln g d p_{t-i}+\theta E C M_{t-1}
$$

In Eq. 10, $\ln$ ser causes $\ln g d p$ if either $\lambda$ is statistically significant (the long-run causality) or the all $a$ are jointly significant (short-run causality). Similarly, in Eq. 11, $\ln g d p$ causes ln ser if either $\theta$ is statistically significant (the long-run causality) or all $b$ are jointly significant (short-run causality).

As a test of robustness, we also use the autoregressive distributed lag models (ARDL) bounds testing procedure proposed by Pesaran et al. (2001). Mah (2000) argues that Engle and Granger (1987), Johansen (1988) and Johansen and Juselius (1990) approaches of cointegration are not reliable in the case of small sample size. Furthermore, Kremers et al. (1992) notes no cointegration can be established among the $I(1)$ variables in the case of small sample size. Therefore, researchers use ARDL due to its various advantages over other cointegration techniques for testing the existence of a linear long-run relationship between the series.

The time-series literature prefers ARDL modeling among other techniques due to several advantages. For example, Pesaran and Shin (1999) argue that small sample properties of ARDL approach are far superior to the Johansen and Juselius cointegration technique. Furthermore, ARDL modeling technique does not impose the restrictive assumption that all under consideration variables should have the same order of integration, but it can be applied irrespective of whether the variable are $I(0), I(1)$ or fractionally cointegrated (Pesaran and Pesaran 1997). The endogeneity is less a problem in ARDL framework because it is free of residual correlation. Pesaran and Shin (1999) have shown that the ARDL method can distinguish between dependent and explanatory variables, and the estimation is possible even when the explanatory variables are endogenous (Pesaran and Pesaran 1997; Pesaran et al. 2001). Therefore, the ARDL modeling is adopted in this study, and it involves estimating the following regression:

$$
\begin{aligned}
\Delta \ln g d p_{t}= & \gamma_{0}+\sum_{i=1}^{p} \gamma_{1 i} \Delta \ln g d p_{t-i}+\sum_{i=1}^{p} \gamma_{2 i} \Delta \ln s e r_{t-i}+\sum_{i=1}^{p} \gamma_{2 i} \Delta Z_{t-i}+\lambda_{1} \ln g d p_{t-1} \\
& +\lambda_{2} \ln s e r_{t-1}+\lambda_{3} \ln Z_{t-1}+v_{t}
\end{aligned}
$$

where $\gamma_{0}$ is drift component and $v_{t}$ white noise. Furthermore, the terms with summation signs represent the error correction dynamics, while the second part of the equation with $\lambda_{i}$ corresponds to long-run relationship. The null hypothesis in the equation is $H_{0}$ : $\lambda_{1}=\lambda_{2}=\lambda_{3}=0$. This means the nonexistence of long-run relationship, while the alternative is $H_{1}: \lambda_{1} \neq 0, \lambda_{2} \neq 0, \lambda_{3} \neq 0$.

The calculated $F$ statistics value is compared with two sets of critical values, which are given by the Pesaran et al. (2001).

The cointegration analysis establishes only the relationship among the variables, which does not provide the direction of the causality. More clearly whether growth of services has an impact on the economic growth or vice versa is still not established. In order to ascertain the direction of causality, Granger casualty test has been employed. As ARDL can be applied irrespective of the order of integration (Pesaran et al. 2001), Granger 
causality tests are applicable irrespective of the orders of integration of the underlying variables if it has been established that there exists a long-run equilibrium relationship between the underlying series (Groenewold and Tang 2007). However, in the presence of a long-run relationship, Granger causality test requires the inclusion of a lagged error correction term within a vector error correction model (VECM) in order to capture the short-run deviations of the series from their long-run equilibrium relationship (Narayan and Smyth 2004; Feridun et al. 2009). In vector error correction mechanism, the following regression will be specified for the Granger causality analysis

$$
\begin{aligned}
& \Delta \ln g d p_{t}=\alpha_{0}+\psi_{11}^{p}(L) \Delta \ln g d p_{t}+\psi_{12}^{q}(L) \Delta \ln \operatorname{ser}_{t}+\delta_{1} \mathrm{ECT}_{t-1}+\mu_{1 t} \\
& \Delta \ln \operatorname{ser}_{t}=\alpha_{1}+\psi_{21}^{p}(L) \Delta \ln \operatorname{ser}_{t}+\psi_{22}^{q}(L) \Delta \ln g d p_{t}+\delta_{2} \mathrm{ECT}_{t-1}+\mu_{2 t}
\end{aligned}
$$

where $\psi_{i j}^{p}(L)=\sum_{n=1}^{P_{i j}} \psi_{i j n} L^{1}$ and $\psi_{i j}^{q}(L)=\sum_{n=1}^{Q_{i j}} \psi_{i j n} L^{1}$ where $L$ are the lag operator, which implies that $(L) \Delta \ln g d p_{t}=\Delta \ln g d p_{t-1}$. ECT $T_{\mathrm{t}-1}$ denotes the one-period lagged error correction term, and $\mu_{1 t}$ and $\mu_{2 t}$ represent serially independent random errors with mean zero and finite covariance matrix (Narayan and Smyth 2004). In Eq. 13, $\Delta \ln g d p_{t}$ is regressed on its own lagged values and the lagged values of $\Delta \ln \operatorname{ser}_{t}$, whereas the opposite is the case in Eq. 14. In both equations, $\mathrm{ECT}_{t-1}$ captures the speed of adjustment of the variables in response to a deviation from their long-run equilibrium path. The significance of the differenced explanatory variables based on $F$ statistics indicates the existence of short-term causal effects, whereas the significance of $\mathrm{ECT}_{t-1}$ based on $t$ statistics indicates the existence of a long-term relationship.

\section{Variable construction and data}

Our base model is a bivariate model in which we shall regress the share of services on the real GDP. However, the result may be skeptical in the presence of puzzle that the share of service in the GDP is moving in the opposite direction while the growth rate of real GDP and growth rate of value added are moving in the same direction. Therefore, to test the robustness of the estimated models, we shall incorporate a number of alternative variables for measuring the different levels of services and control variables.

We follow the conventions and measure the economic through real GDP. Even the economic development is measured by the per capita GDP by Lucas (1988). Lucas (1988) argues that the problem of economic development is simply the problem of levels and rate of growth of per capita income. Therefore, the empirical research relies on the data of real GDP for measuring the economic growth and economic development despite the contradiction of Streeten (1994) on the statement of Lucas (1988). We also follow Lucas (1988) by taking the level of real GDP for measuring the economic growth.

The other major variable is share of value-added services in GDP. We also take several sub-sectors of services to test the robustness of our model. More importantly, we are interested to test the Baumol (1967) and Pugno (2006) controversy that whether the business services or household services are important for the economic growth. For this purpose, we take that data of share of wholesale and retail trade (wrt), finance and insurance $(f i)$ and transport storage and communication $(t c)$ in the value-added services. Then, the household services are measured through the share of expenditure on education $(e d u)$ and share of expenditure on health $(h l t)$ as Pugno (2006) suggested. 
The variables are capital, trade openness and inflation, which usually enter in the growth regression. Since the data on the capital stock are not available for the economy of Pakistan, the researchers estimate the capital through various methodologies by taking the various rates of depreciation of capital based on the assumptions about the economies. We will use the perpetual inventory flow method by using the $4 \%$ rates of geometric decay (Jalil et al. 2010). We use Nehru and Dhareshwar (1993) for calculating the initial value of capital stock. If $K(0)$ is the initial stock in period zero and $\delta$ is the rate of depreciation, then the capital stock series (cap) will be generated as $K_{t+1}=I_{t}+(1-\delta) K_{t}$. While the value of $I_{t}$ in the first period is estimated through a linear regression of the log of investment against time, the fitted value of initial investment is used to calculate initial capital stock using the following equation: $K_{t}=I_{t} / I_{t}(g+\delta)$. Here, $g$ is the rate of growth of GDP. Trade openness (open) is the ratio of value of exports plus value of imports to real GDP, and inflation (cpi) is measured by the natural log of consumer price index.

All data are taken from 1960 to 2014. The major sources of the data are the various issues of economic survey of Pakistan and the Handbook of Statistics (SBP 2010). Furthermore, we divide the sample into two parts to test the robustness of the results. We take the sample from 1973 to 2014. We have a justification that East Pakistan was separated into Bangladesh in 1971. Therefore, there may be a structural break in the data set. Furthermore, we are using the ARDL that provides the consistent results in the case of sample size. Therefore, our implied methodologies allow us for using the different sample sizes.

\section{Empirical results}

Testing the stationary properties of a data is a natural start of an empirical analysis in a time-series data setting. For this purpose, we use two most popular methodologies: ADF and PP. The results are presented in Table 1.

It is evident from the table the both tests are giving contradictory results in different equations. Several variables appear to be stationary even at levels, and some others are stationary at first difference. However, it is clear that none of the variables is stationary at second difference. We have mentioned about ARDL cointegration technique. This can be applied irrespective of $I(0)$ or $I(1)$. But, Perron (1989) notes that the power of conventional unit root tests decreases in the presence of structural break. Therefore, the result of $\mathrm{ADF}$ test may mislead due to the fact the under consideration variables may contain structural breaks. We may allow exogenous structural break in ADF tests to avoid this problem. For this purpose, Zivot and Andrews (1992) and Perron (1997) propose determining the break point 'endogenously' from the data. The researchers frequently use the Clemente-Montanes-Reyes (CMR hereafter) (1998) unit root tests. The major advantage of CMR unit root test is that they do not require an a priori knowledge of the structural break dates. This test allows two structural breaks in the mean of the series with the null hypothesis that the series has a unit root with structural break(s) against the alternative hypothesis that they are stationary with break(s). Two models are estimated under the CMR unit root tests. First, an additive outliers (AO) model captures a sudden change in the mean of a series. Second, an innovational outliers (IO) model allows for a gradual shift in the mean of the series. In this thesis, both models will be used. As evident from Table 2, the structural breaks suggested by CMR unit root tests are significant at $5 \%$ level of significance. 
Table 1 Unit root tests without structural breaks

\begin{tabular}{|c|c|c|c|c|c|c|c|c|}
\hline & $\tau_{u}$ & $\tau_{t}$ & $\tau$ & & $\tau_{u}$ & $\tau_{t}$ & $\tau$ & Method \\
\hline \multirow[t]{2}{*}{$\ln g d p$} & -0.420 & -1.690 & $6.030^{\mathrm{a}}$ & $\Delta \ln g d p$ & $-4.680^{a}$ & $-4.650^{\mathrm{a}}$ & NA & $P P^{b}$ \\
\hline & -0.400 & -1.770 & 2.130 & & $-4.700^{\mathrm{a}}$ & $-4.640^{\mathrm{a}}$ & $7.319^{a}$ & $\mathrm{ADF}^{\mathrm{C}}$ \\
\hline \multirow[t]{2}{*}{ Iser } & -1.787 & -1.290 & $5.040^{\mathrm{a}}$ & $\Delta /$ ser & $-3.600^{\mathrm{a}}$ & $-4.523^{\mathrm{a}}$ & NA & PP \\
\hline & 0.891 & -1.740 & 2.130 & & $-3.610^{\mathrm{a}}$ & $-3.750^{\mathrm{a}}$ & $-4.850^{\mathrm{a}}$ & ADF \\
\hline \multirow[t]{2}{*}{ Iwrt } & -1.440 & -2.060 & 2.950 & $\Delta / w r t$ & $-3.690^{a}$ & $-3.720^{\mathrm{a}}$ & -2.610 & PP \\
\hline & -1.540 & -1.990 & $4.060^{\mathrm{a}}$ & & $-3.650^{\mathrm{a}}$ & $-3.670^{a}$ & NA & ADF \\
\hline \multirow[t]{2}{*}{ fi } & 0.620 & -2.660 & $4.500^{\mathrm{a}}$ & $\Delta f i$ & $-3.650^{\mathrm{a}}$ & $-3.740^{\mathrm{a}}$ & NA & PP \\
\hline & 1.010 & -2.770 & 2.900 & & $-3.690^{a}$ & $-3.760^{\mathrm{a}}$ & -2.090 & ADF \\
\hline \multirow[t]{2}{*}{ tc } & -2.420 & -0.890 & $12.510^{\mathrm{a}}$ & $\Delta t c$ & $-4.620^{a}$ & $-5.070^{a}$ & $-N A$ & PP \\
\hline & -2.400 & -0.860 & $14.260^{\mathrm{a}}$ & & $-4.640^{\mathrm{a}}$ & $-5.060^{a}$ & NA & ADF \\
\hline \multirow[t]{2}{*}{ edu } & -0.420 & -1.690 & $6.030^{\mathrm{a}}$ & $\Delta e d u$ & $-4.680^{\mathrm{a}}$ & $-4.650^{\mathrm{a}}$ & NA & PP \\
\hline & -0.400 & -1.770 & $7.130^{\mathrm{a}}$ & & $-4.700^{\mathrm{a}}$ & $-4.640^{\mathrm{a}}$ & NA & ADF \\
\hline \multirow[t]{2}{*}{$h / t$} & -2.850 & -2.840 & -0.250 & $\Delta h / t$ & $-7.180^{\mathrm{a}}$ & $-7.150^{\mathrm{a}}$ & $-7.360^{\mathrm{a}}$ & PP \\
\hline & -2.770 & -2.750 & -0.200 & & $-6.220^{\mathrm{a}}$ & $-6.130^{a}$ & $-6.310^{a}$ & ADF \\
\hline \multirow[t]{2}{*}{ Icap } & -2.100 & -1.980 & 0.000 & $\Delta / c a p$ & $-4.510^{\mathrm{a}}$ & $-4.380^{\mathrm{a}}$ & $-4.610^{a}$ & PP \\
\hline & -2.420 & $-4.300^{a}$ & -0.120 & & $-4.490^{\mathrm{a}}$ & NA & $-4.560^{\mathrm{a}}$ & ADF \\
\hline \multirow[t]{2}{*}{ lopen } & -2.850 & -2.840 & -0.250 & Slopen & $-7.180^{\mathrm{a}}$ & $-7.150^{\mathrm{a}}$ & $-7.360^{\mathrm{a}}$ & PP \\
\hline & -2.770 & -2.750 & -0.200 & & $-6.220^{\mathrm{a}}$ & $-6.130^{a}$ & $-6.310^{a}$ & ADF \\
\hline \multirow[t]{2}{*}{ Iсpi } & -1.780 & $-4.290^{a}$ & $5.040^{\mathrm{a}}$ & $\Delta / c p i$ & $-3.600^{\mathrm{a}}$ & NA & NA & PP \\
\hline & 0.890 & -2.740 & 3.130 & & $-3.610^{a}$ & $-3.750^{\mathrm{a}}$ & NA & ADF \\
\hline
\end{tabular}

$\tau_{u}$ is the model with an intercept and without trend; $\tau_{t}$ represents with an intercept and trend; and $\tau$ is without an intercept and trend

a Implies that the data series is stationary

b PP is an abbreviation of Phillips and Perron test for unit root

c Abbreviation of augmented Dickey-Fuller test for unit root

Table 2 Unit test with two structural breaks

\begin{tabular}{|c|c|c|c|c|c|c|c|c|}
\hline & Innovat & outliers & & & Additive & utliers & & \\
\hline & $t$ stat & TB1 & TB2 & Decision & $t$ stat & TB1 & TB2 & Decision \\
\hline $\ln g d p$ & -4.864 & $1997^{*}$ & $1996^{*}$ & $/(1)$ & -4.89 & $2000^{*}$ & $1997^{*}$ & $/(1)$ \\
\hline Iser & -3.53 & $2001^{*}$ & $1997^{*}$ & $/(1)$ & -4.18 & $1994^{*}$ & $1997^{*}$ & $/(1)$ \\
\hline Iwrt & -4.345 & $2001^{*}$ & $2003^{*}$ & $/(1)$ & 3.769 & $1998^{*}$ & $2003^{*}$ & $/(1)$ \\
\hline fi & -4.284 & $2000^{*}$ & $2004^{*}$ & $/(1)$ & 7.684 & $2001^{*}$ & $2005^{*}$ & $/(1)$ \\
\hline tc & -5.889 & $1997^{*}$ & $2000^{*}$ & $/(1)$ & 6.817 & 1999* & $2005^{*}$ & $/(1)$ \\
\hline edu & -7.864 & $2001^{*}$ & $2003^{*}$ & $/(1)$ & 4.556 & $1997^{*}$ & $2003^{*}$ & $/(1)$ \\
\hline$h / t$ & -4.738 & $2000^{*}$ & $2005^{*}$ & $/(1)$ & 6.100 & $1989^{*}$ & $1998^{*}$ & $/(1)$ \\
\hline Icap & -5.821 & $1986^{*}$ & $2004^{*}$ & $/(1)$ & 4.290 & $1997^{*}$ & $2003^{*}$ & $/(1)$ \\
\hline lopen & -4.781 & $1997^{*}$ & $2002^{*}$ & $/(1)$ & 5.716 & $2001^{*}$ & $2006^{*}$ & $/(1)$ \\
\hline Iсpi & -7.031 & $2001^{*}$ & $2006^{*}$ & $/(1)$ & 7.479 & $1998^{*}$ & $2001^{*}$ & $/(1)$ \\
\hline
\end{tabular}

Though CMR unit root tests suggest that all series are $I(1)$, we can easily apply Johansen cointegration. However, due to the contradiction among ADF, PP and CMR results in the case of $\ln g d p$, ln ser and several other variables, the authors prefer ARDL approach over Johansen cointegration approach for detailed analysis of long-run relationship. However, we shall start with Johansen cointegration for testing the bivariate model by estimating Eqs. 10 and 11. The results are presented in Table 3. 
Table 3 Test of cointegration of bivariate model

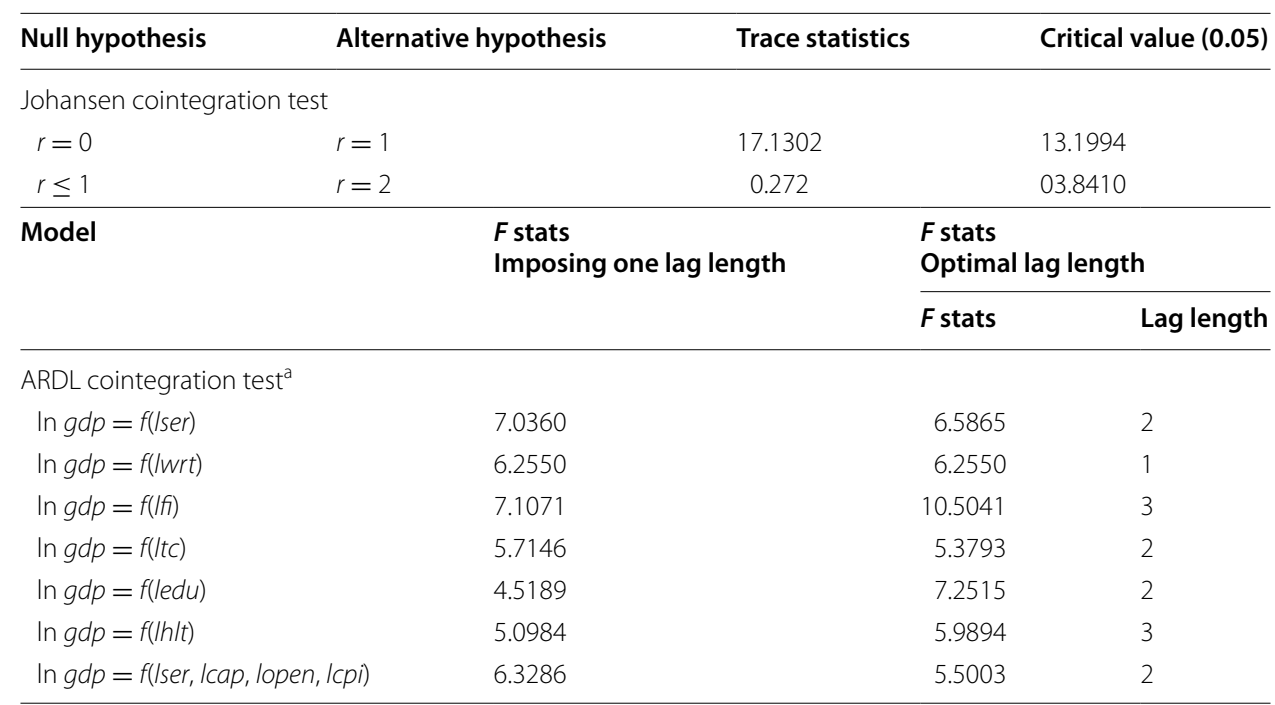

a The calculated values are compared with critical values of Pesaran et al. (2001)

The comparison of calculated trace statistics value with the critical value at $5 \%$ level of significance clearly indicates that the null hypothesis of zero cointegration vectors is rejected while the null hypothesis of one cointegrating vector is accepted. Thus, we can conclude that $\ln g d p$ and $\ln s e r$ are cointegrated. That is, there is a long-run relationship between real GDP and services sector of Pakistan.

Furthermore, as mentioned earlier for the robustness purposes we also use ARDL cointegration technique. The results of ARDL cointegration test are mentioned in the lower panel of Table 3. The choosing of lag length is an important task here. We follow two strategies. First, following Ang (2010), we impose one lag length keeping the small sample of the data. It is important to mention here that the any autoregressive model is sensitive to the number of lags. Therefore, as a second strategy we use the optimal lag length based on the Akaike information criteria (AIC). We estimated seven different models for testing the long-run relationship among the variables; six out of seven models are bivariate models which contain single measure of services sector of the righthand side, while the seventh model is regressed with some other control variables to test the robustness of the sign and significance of services sector. It is evident from the result that all models show strong evidence of long-run relationship among the variables.

We have established the long-run association among the variables through the cointegration analysis. But, yet we are not sure that which variable is causing the other variable. For this purpose, we estimate Eqs. 13 and 14 for the Granger causality test. The results are presented in Table 4.

Table 4 Granger causality test

\begin{tabular}{lll}
\hline Null hypothesis & F statistics & Prob \\
\hline In ser does not Granger cause In gdp & 4.1964 & 0.0484 \\
In gdp does not Granger cause In ser & 0.4492 & 0.4239 \\
\hline
\end{tabular}


Table 5 Long-run estimates through ARDL

\begin{tabular}{|c|c|c|c|c|c|c|c|}
\hline Regressor & Model 1 & Model 2 & Model 3 & Model 4 & Model 5 & Model 6 & Model 7 \\
\hline \multicolumn{8}{|c|}{ In $g d p$ is dependent variable } \\
\hline \multirow[t]{2}{*}{ Iser } & $0.6769^{* * *}$ & NA & NA & NA & NA & NA & $0.3062^{* * *}$ \\
\hline & $(0.2395)$ & NA & NA & NA & NA & NA & $(0.1188)$ \\
\hline \multirow[t]{2}{*}{ Iwrt } & NA & $0.3885^{* *}$ & NA & NA & NA & NA & NA \\
\hline & NA & $(0.1948)$ & NA & NA & NA & NA & NA \\
\hline \multirow[t]{2}{*}{ fi } & NA & NA & $0.6295^{* * *}$ & NA & NA & NA & NA \\
\hline & NA & NA & $(0.2659)$ & NA & NA & NA & NA \\
\hline \multirow[t]{2}{*}{ tc } & NA & NA & NA & $0.5261^{* * *}$ & NA & NA & NA \\
\hline & NA & NA & NA & $(0.2111)$ & NA & NA & NA \\
\hline \multirow[t]{2}{*}{ edu } & NA & NA & NA & NA & $0.8060^{* * *}$ & NA & NA \\
\hline & NA & NA & NA & NA & $(0.2163)$ & NA & NA \\
\hline \multirow[t]{2}{*}{$h / t$} & NA & NA & NA & NA & NA & -0.3579 & NA \\
\hline & NA & NA & NA & NA & NA & $(0.2993)$ & NA \\
\hline \multirow[t]{2}{*}{ Icap } & NA & NA & NA & NA & NA & NA & $0.3615^{* *}$ \\
\hline & NA & NA & NA & NA & NA & NA & $(0.1698)$ \\
\hline \multirow[t]{2}{*}{ lopen } & NA & NA & NA & NA & NA & NA & $0.3706^{* * *}$ \\
\hline & NA & NA & NA & NA & NA & NA & $(0.1562)$ \\
\hline \multirow[t]{2}{*}{ Iсpi } & NA & NA & NA & NA & NA & NA & $-0.7459^{*}$ \\
\hline & NA & NA & NA & NA & NA & NA & $(0.4287)$ \\
\hline \multirow[t]{2}{*}{$\mathrm{ECM}_{t-1}$} & $-0.3702^{* *}$ & $-0.1656^{* * *}$ & $-0.3626^{* *}$ & $-0.3839^{* * *}$ & $-0.7519^{*}$ & $-0.2030^{*}$ & $-0.5176^{* * *}$ \\
\hline & $(0.1611)$ & $(0.0686)$ & $(0.1768)$ & $(0.1024)$ & $(0.4187)$ & $(0.1201)$ & $(0.1785)$ \\
\hline \multicolumn{8}{|l|}{ Diagnostics test } \\
\hline Functional form & 0.7361 & 0.8789 & 0.7119 & 0.1358 & 0.1965 & 0.5814 & 0.2763 \\
\hline Normality & 0.7901 & 0.4840 & 0.4236 & 0.6873 & 0.5111 & 0.3191 & 0.5782 \\
\hline Heteroscedasticity & 0.2660 & 0.4599 & 0.7574 & 0.8706 & 0.7383 & 0.2651 & 0.5002 \\
\hline Serial correlation & 0.1175 & 0.7799 & 0.1442 & 0.0927 & 0.3799 & 0.8890 & 0.1568 \\
\hline CUSUM & Stable & Stable & Stable & Stable & Stable & Stable & Stable \\
\hline CUSUMSQ & Stable & Stable & Stable & Stable & Stable & Stable & Stable \\
\hline
\end{tabular}

Standard errors of the coefficients in parenthesis indicates the significance levels

***,**,* indicates significance at $1 \%, 5 \%$ and $* 10 \%$, respectively

The null hypothesis $\ln s e r$ does not Granger cause $\ln g d p$ is rejected at $5 \%$ level of significance which implies that the services sector may be a pivotal determinant of the real GDP in Pakistan. While the acceptance of null hypothesis $\ln g d p$ does not Granger cause In ser implies that the causality does not run other way.

After establishing a long-run relationship and direction of causality, the next task is to estimate the error correction model for the long-run elasticities and error correction term. For this purpose, we use the ARDL estimators. The results are presented in Table 5. The table contains only the long-run estimates, while the short-run estimates are not presented keeping brevity in mind. ${ }^{1}$

It is evident from model 1 that the variable $\ln s e r$, which is a measure of share of valueadded services in the GDP of Pakistan, enters significantly positive in the regression, which implies that the services sector has a positive impact on the economic activities of Pakistan. This finding is in line with that by Sundrum (1990), Illeris (1996), Qin (2006) and Pugno (2006) that it is a natural process for a developing economy to evolve into

\footnotetext{
${ }^{1}$ However, the short-run results are available from corresponding author on request.
} 
a services-oriented economy. However, the findings of the present study are sharply in contrast to Baumol (1967) and Baumol et al. (1985), which points out the servicesled growth is a demand-driven growth and demand-driven economic growth always remains shaky in its nature. However, Fixler and Siegel (1999), Greenhalg and Gregory (2001), Oulton(2001) and Baumol (2001) recognize that the business-related services lead toward the economic growth of an economy, while the household services are the burden on an economy.

To test this preposition, we take several business- and household-related service variables. It is evident that from model 2 to model 6 the services-related variable enters significantly positive in the growth regression whether it is related to business or household activities like education- and health-related expenditure. In this way, our findings are in line with the theoretical model of Pugno (2006), which reconciles the puzzle through the endogenous growth model. Furthermore, there are several factors that may affect the business activities of a country, for example physical capital, trade openness and inflation. We also incorporate these variables to test the robustness of the sign and significance of services variable. The model 7 shows that the sign and significance level of services remain robust and do not alter the results. The measure of capital stock, trade openness and inflation enters in the regression according to the a priori expectation.

In addition, to testing the robustness of our model we re-estimated all seven models with a shorter sample size. We take the sample from 1973 to 2014, keeping the fact in view that East Pakistan was separated in 1971 and there may be some aggregation bias in pre-1971 data. Since we are using ARDL technique for estimating the error correction model, this methodology allows us to get super consistent results even in a short span of time. As expected, our findings do not alter in the shorter span of time. ${ }^{2}$

The ECM term of the each model is presented in Table 5. The term is correct in sign, which is negative and significant in all cases. The negative sign implies that any disequilibrium in the short run will be converging to the long-run equilibrium. However, the magnitude of the ECM term varies from case to case. Specifically, it varies from -0.1656 to -0.7519 . The magnitudes of the ECM term show the speed of adjustment of a shock in short run, which will be adjusted in the long run. More clearly, -0.1656 implies that any exogenous shock in the economic growth will be adjusted in approximately 5 and half years.

Further to test the health of our estimated model, we pass through our regression through various statistical tests. Our estimated models pass through model. The reported $\mathrm{p}$ values in Table 5 show that the null hypotheses of correct functional form, normal distribution of error, homoscedastic errors and no serial correlation are accepted for all almost every model except model 4. In addition, we test the stability of the models through well popular by using Brown et al. (1975) stability test as suggested by Pesaran et al. (2001). This test is well known as cumulative (CUSUM) and cumulative sum of squares (CUSUMSQ). The calculated values of CUSUM and CUSUMSQ statistics are well within the critical bounds at $5 \%$ level of significance. ${ }^{3}$ It implies that the coefficients in the error correction model are stable.

\footnotetext{
${ }^{2}$ We are not presenting the results here for saving the space of article.

${ }^{3}$ However, we do not present here the 14 graphs of CUSUM and CUSUMSQ keeping brevity in mind.
} 


\section{Conclusion}

This article empirically tests the hypothesis of Pugno (2006) that the services sector, whether it is business related or household related, positively related to the economic growth of a country. We test this hypothesis in the case of Pakistan. According to our understanding, Pakistan is a good candidate in this context, since the economy of Pakistan witnessed a miracle growth in GDP from 2000 to 2006. Indeed, according to the annual reports of State Bank of Pakistan, the services sector was the major contributor in this miraculous economic growth. But suddenly that miracle evaporated and economy of Pakistan witnessed a free fall from $8 \%$ annual growth in 2006 to $2 \%$ growth in 2011 and 2012.

For this purpose, we estimate the bivariate model of Singh (2010) under the ARDL framework over the period of 1960-2014. We also use the Johansen cointegration for the robustness of the results, because augmented Dickey-Fuller test and Phillips-Perron tests give contradictory results about the order or integration. Then, we allow the structural breaks in the data series and apply the Clemente-Montanes-Reyes unit root test. This test shows that all the series have the same order of integration and are stationary at first difference. Therefore, in the presence contradictory evidences on the order of integration we use two different cointegration methodologies. However, we rely on ARDL for the estimation of error correction model as it can be applied irrespective of $I(0)$ or $I(1)$.

Our findings are in line with Pugno (2006) that the services sector contributes in the economic growth of a country regardless of the fact that whether these services are business related or household related. Therefore, the findings of the study suggest that the promotion of services sector may improve the growth of Pakistani economy. Therefore, the policy makers should concentrate on the household- or business-related services. But it is important to mention here that Pakistan should adopt a gradual policy for the transition from industrialization era to the post-industrialization as done by China over the last three decades. Otherwise, if we rely exclusively on the services sectors for the economic growth, as we have done in the first half of the decade 2000, then our growth will vulnerable to any external or internal shock.

Authors' contributions

AJ, SM and SS proposed the methodology and provided policy implications. SM was in charge of data collection and conducted data analysis. AJ and SS wrote the paper. All authors read and approved the final manuscript.

Author details

${ }^{1}$ School of Economics, Quaid-i-Azam University, Islamabad, Pakistan. ${ }^{2}$ Pakistan Institute of Development Economics, Islamabad, Pakistan.

\section{Acknowledgements}

The basic idea of the article was presented in a seminar at School of Economics. We are thankful to Prof. Aliya H. Khan and the other participants of the seminar for their candid feedback.

Competing interests

The authors declare that they have no competing interests.

Received: 4 October 2015 Accepted: 3 February 2016

Published online: 02 March 2016 
Baumol WJ (2001) Paradox of the services: exploding costs, persistent demand. In: ten-Raa T, Schettkat R (eds) The growth of service industries: the paradox of exploding costs and persistent demand. Elgar, Cheltenham, pp 3-28

Baumol WJ, Blackman B, Wolff EN (1985) Unbalanced growth revisited: asymptotic stagnancy and new evidence. Am Econ Rev 75(4):806-817

Baumol WJ, Blackman B, Anne S, Wolff EN (1989) Productivity and American leadership: the long view. MIT Press, Cambridge

Brown RL, Durbin J, Evans JM (1975) Techniques for testing the constancy of regression relations over time. J R Stat Soc $37: 149-163$

Chenery HB (1979) Structural change and development policy. Oxford University Press, Washington

Chenery HB, Syrquin M (1975) Patterns of development 1950-70. Oxford University Press, Oxford

Clemente J, Montanes A, Reyes M (1998) Testing for a unit root in variables with a double change in the mean. Econ Lett 59:175-182

Echevarria C (1997) Changes in sectoral composition associated with economic growth. Int Econ Rev 38:431-452

Engle R, Granger C (1987) Co-integration and error correction representation: estimation and testing. Econometrica $55: 251-276$

Faria JR (2001) Does high inflation affect growth in the long run. J Appl Econ 4:89-105

Feridun M, Bansi S, Jalil A (2009) Stock market and investment in an emerging economy: the case of Turkey. Ekonomska Istrazivanja-Econ Res 22:17-29

Fixler DJ, Siegel D (1999) Outsourcing and productivity growth in services. Struct Change Econ Dyn 10:177-194

Gramlich EM (1994) Infrastructure investment: a review essay. J Econ Lit 32:1176-1196

Greenhalg C, Gregory M (2001) Structural change and the emergence of the new service economy. Oxford Bull Econ Stat 63:629-646

Groenewold N, Tang SHK (2007) Killing the goose that lays the golden egg: institutional change and economic growth in Hong Kong. Econ Inq 45:787-799

Grossman GE, Helpman E (1991) Endogenous product cycle. Econ J 101:1214-1229

Illeris S (1996) The service economy: a geographical approach. Wiley, Chichester

Jalil A, Feridun M, Ma Y (2010) Finance-growth nexus in China revisited: new evidence from principal components and ARDL bounds tests. Int Rev Econ Finance 19:189-195

Johansen S ( 1988) Statistical analysis of cointegration vectors. J Econ Dyn Control 12(2-3):231-254

Johansen S (1991) Estimation and hypothesis testing of co-integration vectors in Gaussian vector autoregressive models. Econometrica 59:1551-1580

Johansen S, Juselius K (1990) Maximum likelihood estimation and inference on cointegration-with applications to the demand for money. Oxford Bull Econ Stat 52:169-210

Kremers JJM, Ericsson NL, Dolado J (1992) The power of cointegration tests. J Econom 52:389-402

Kuznets S (1957) Quantitative aspects of the economic growth of nations: part 2, industrial distribution of national product and labor force. Econ Dev Cult Change 5:1-111

Kuznets S (1966) Modern economic growth: rate, structure and spread. Yale University Press, New Haven

Kuznets S (1971) Economic growth of nations: total output and production structure. Harvard University Press, Cambridge

Levine R (1997) Financial development and economic growth: views and agenda. J Econ Lit 35:688-726

Levine R, Zervos S (1998) Stock markets, banks, and economic growth. Am Econ Rev 88:537-558

Levine R, Loayza N, Beck T (2000) Financial intermediation and growth: causality and causes. J Monet Econ 46:31-77

Lucas R (1988) On the mechanics of economic development. J Monet Econ 22:3-42

Mah JJ (2000) An empirical examination of the disaggregated import demand of Korea - the case of information technology products. J Asian Stud 11:233-244

Munnell AH (1992) Policy watch: infrastructure investment and economic growth. J Econ Perspect 6:189-198

Narayan PK, Smyth R (2004) The relationship between the real exchange rate and balance of payments: empirical evidence for China from co-integration and causality testing. Appl Econ Lett 11:287-291

Nehru V, Dhareshwar A (1993) A new database on physical capital stock: sources, methodology and results. Revista de Analisis Economica 8:37-59

Oulton N (2001) Must the growth rate decline? Baumol's unbalanced growth revisited. Oxford Econ Pap 53:605-627

Perron P ( 1989) The great crash, the oil price shock, and the unit root hypothesis. Econometrica, Econometric Society, 57(6), 1361-1401

Perron P (1997) Further evidence on breaking trend functions in macroeconomic variables. J Econom 80:355-385

Pesaran MH, Pesaran B (1997) Microfit 4.0 (Window Version). Oxford University Press, New York

Pesaran MH, Shin Y (1999) An autoregressive distributed lag modelling approach to cointegration analysis. In: Strom S (ed) Econometrics and economic theory in 20th century: the Ragnar Frisch Centennial Symposium, Chapter 11. Cambridge University Press, Cambridge

Pesaran MH, Shin Y, Smith RJ (2001) Bounds testing approaches to the analysis of level relationships. J Appl Econom 16:289-326

Pradhan RP, Bagchi TP (2013) Effect of transportation infrastructure on economic growth in India: the VECM approach. Res Transp Econ 38:139-148

Pugno M (2006) The service paradox and endogenous economic growth. Struct Change Econ Dyn 17:99-115

Qin D (2006) Is China's growing service sector leading to cost disease? Struct Change Econ Dyn 17:267-287

Rostow WW (1971) The stages of economic growth. Cambridge University Press, Cambridge

Roubini N, Sala-i-Martin X (1992) Financial repression and economic growth. J Dev Econ 39:5-30

Sargan JD (1964) Wages and prices in the United Kingdom. In: Hart PE, Mills G, Whitaker JK (eds) Econometric analysis for national economic planning. Butterworths, London

Sidrauski M (1967) Rational choice and pattern of growth in a monetary economy. Am Econ Rev 57:534-544

Singh T (2010) Services sector and economic growth in India. Appl Econ 42:3925-3941

State Bank of Pakistan (2010) Handbook of statistics 2010 
Streeten P (1994) Human development: means and ends. In: The American economic review, papers and proceedings of the hundred and sixth annual meeting of the American Economic Association vol 84, pp 232-237

Sundrum RM (1990) Economic growth in theory and practice. MacMillan, Houndmills

Young A (1991) Learning by doing and the dynamic effects of international trade. Q J Econ 106:369-405

Zivot E, Andrews DWK (1992) Further evidence on the great crash, the oil-price shock, and the unit-root hypothesis. J Bus Econ Stat 10:251-270

Submit your manuscript to a SpringerOpen ${ }^{\circ}$ journal and benefit from:

- Convenient online submission

- Rigorous peer review

- Immediate publication on acceptance

- Open access: articles freely available online

- High visibility within the field

- Retaining the copyright to your article

Submit your next manuscript at $\boldsymbol{\triangleright}$ springeropen.com 